Ожнигова Людмила Николаевна

д-р психол. наук, профессор

Клемперт Светлана Владимировна

магистрант

ФГБОУ ВО «Кубанский государственный университет» г. Краснодар, Краснодарский край

DOI $10.21661 / \mathrm{r}-553936$

\title{
УДОВЛЕТВОРЕННОСТЬ СОБСТВЕННЫМ ТЕЛОМ И ОТНОШЕНИЕ К ЗДОРОВЬЮ У МОЛОДЫХ ДЕВУШЕК
}

Аннотация: в статье рассматривается проблема удовлетворенности собственным телом и отночение к здоровью у молодых девушек. Было отмечено, что изучение темы внешности ило в трех направлениях: во-первых, изучение различных типов суждений, выносимых на основе внешнего облика; во-вторых, изучение влияния различных аспектов внешности на эти сужсения; в-третьих, изучение самовосприятия внешнего облика самим индивидом. Авторов более всего интересует третье направление, в рамках которого и изучалось отношение к собственной внешности молодых девушек, удовлетворенность собственным телом. Выявлено, что в рамках этого направления выделяются различные компоненты, которые влияют на удовлетворенность образом собственного тела и, мы заметили, что среди данных компонентов здоровье встречается реже всего. Авторами статьи были уточнены понятия таких феноменов, как «образ тела» и «здоровье». Также в ходе эмпирического исследования было доказано, что связь между удовлетворенностью собственным телом $и$ отночением к здоровью у молодых девушек отсутствует.

Ключевые слова: удовлетворенность собственным телом, самоотношение, здоровье, отночение девушек к своему здоровью.

В современном обществе большой интерес вызывает идея о том, что успех женщины коррелирует с ее привлекательной внешностью, поэтому труднодостижимый в реальности образ становится одним из факторов глобального 
самоотношения и чувства удовлетворенности (или неудовлетворенности) собой

[5]. В ряде исследований показано, что удовлетворенность собой в целом [14], своей внешностью и состоянием своего здоровья являются составляющими субъективного благополучия личности [4].

На текущий момент среди факторов, влияющих на формирование отношения к своему телу, здоровью, чаще всего выделяют: различные культурные стереотипы, общественные нормы, средства массовой информации, семейные отношения и другие значимые для человека аспекты. Несмотря на это, в отечественной литературе недостаточно исследований по изучению особенности удовлетворенности своим телом у молодых женщин, формирование отношения к своему физическому Я [8].

В позднем юношеском возрасте (18-25 лет) для девушек характерно испытывать болезненное внимание к таким критериям внешности, как рост тела, его размер, вес, пропорции, прическа, лицо и многих других. При этом, многим из них, хотелось бы свой внешний облик изменить. Это происходит потому, что, зачастую, оценки в отношении собственного тела со стороны молодых женщин, не отличаются объективностью, а, даже, напротив, порой, полностью противоречат мнению представителей социального окружения. Огромное влияние на женские представления о своем теле оказывают разного рода социальные реакции (одобрение, насмешка, восхищение) которые, неминуемо, включаются в их представление о самих себе.

В настоящей работе исследование посвящено поиску ответа на проблемный вопрос: является ли удовлетворенность собственным телом и отношение к здоровью существенным свойством личности у молодых девушек.

Рост интереса к проблеме внешности привел к тому, что в 1970-х и 1980-х гг. ХX века наблюдалось значительное увеличение исследований в зарубежной психологии. По мнению Н. Рамси, Д. Харкорт изучение данной темы шло в трех направлениях: 1) особенности восприятия внешности другими людьми (суждения, выносимые на основе внешности и влияние различных аспектов внешности на поведение других); 2) психологию физических недостатков и, наконец; 3) 
исследование телесного образа, понимаемого, в широком смысле, как самовосприятие внешности [10].

Внешний облик определяют в американской психологии как физическую характеристику, которая включает в себя пропорции телосложения, черты лица, рост, цвет кожи и пр. Подчеркивается культурная и социальная обусловленность оценки внешности как привлекательной или непривлекательной [7]. Именно социум создает стереотипы представлений о красоте, несоответствие личности этим стереотипам вызывает отрицательное и отчужденное отношение общества [15]. Переживания негативных эмоций по поводу неодобрительной оценки собственной внешности могут приводить к возрастанию тревоги, депрессии, к формированию феномена страха перед оценкой внешнего облика [16], переоценки гендерной идентичности личности [17].

Отношение личности к собственному внешнему облику отражается на общей картине благополучия жизни, перестройке социально-психологической ситуации развития личности. Трансформируются сферы общения, изменяются взаимодействия между полами, терпят изменения гендерные роли, уровень самооценки и прочее. В итоге, социально-психологические показатели, приводящие к определенному отношению к своему внешнему облику, становятся важными регуляторами поведения личности.

В современной психологической науке растет интерес к интересующему нас третьемунаправлению - исследование телесного образа, понимаемого, в широком смысле, как самовосприятие внешности, в рамках которого и было принято изучать отношение к собственной внешности, удовлетворенность собственным телом.

Е.Т. Соколова выделила 3 подхода к рассмотрению понятия образа тела в зарубежной психологии.

В рамках первого подхода психологи исследуют структуры мозга и рассматривают «образ тела» как результат активности определенных нейронных систем. Психологическая наука не считает понятие «образ тела» тождественным «схеме тела», тогда как физиологи считают их тождественными. Например, П. Федерн 
под схемой тела имеет в виду некое постоянное знание о нем, а под «образом тела» - его ситуативную психическую репрезентацию. Согласно другим взглядам, «схема тела» - это проприоцептивные ощущения, тогда как «образ тела»осознанное или неосознанное психическое отражение.

Второй подход под «образом тела» понимает умственную картину собственного тела, какой она представлена индивиду в его сознании. Представлением индивида о том, как его тело воспринимают другие, считает «образ тела» Д. Чаплин. Д. Беннет находит в образе тела две составляющие: зрительную картину собственного тела или восприятие тела, и набор признаков, с помощью которых индивид описывает свое тело, или концепция тела.

Третий подход под «образом тела» понимает «сложное комплексное единство восприятия, установок, оценок, представлений, связанных и с телесной внешностью, и с функциями тела». Представителем третьего подхода являлся автор термина «образ тела» П. Шильдер. Он определял «образ тела» как субъективный пространственный опыт восприятия тела, которые формируется и трансформируется в процессе общения с другими людьми и включает в себя когнитивный, перцептивный и эмоциональный компоненты [13].

Исследования содержания образа тела в рамках теории о Я-концепции и «целостном Я» проводилось такими авторами, как А.А. Налчаджян [6], В.А. Подорога [9], Е.Т. Соколова и др. в качестве одного из важнейших компонентов самосознания. В процессе структуры развития человека телесный образ «Я» изменяется под воздействием социально-культурных компонентов.

Образ тела - психологический термин; в образе тела имеются представления о теле как плоти и о теле как телесности, а это означает, что сам образ тела может выступать как эмпирически наблюдаемый и как исследуемый объект.

Исходя из того, что понятие «образ тела» имеет различное происхождение и сложную структуру, рассмотрев позиции разных авторов, разрабатывающих проблематику образа тела, можно выделить следующие компоненты, встречающиеся в работах: границы образа тела, внешний облик, телесность и полоролевая принадлежность [2]. 
В рамках этого направления выделяются различные компоненты, которые влияют на удовлетворенность образом собственного тела и, но среди изучаемых компонентов здоровье встречается реже всего.

Современное понимание целостного феномена здоровья подразумевает наличие в нем физического, психического, социального и духовно-нравственного компонентов.

В качестве одного из комплексных и наиболее значимых психологических факторов здоровья выделяют единое смысловое, ценностное и эмоциональнооценочное образование, существующее в психике каждого человека, - «отношение к здоровью» по Р.А. Березовской, «внутренняя картина здоровья» по В.А. Ананьеву[1], И.И. Мамайчук, «социальные представления о здоровье» по О.С. Васильевой, Ф.Р. Филатову [3] и т. д. Исследователи Д. Сиерес, В. Гавидия используют для этих целей термин «индивидуальная концепция здоровья» [11].

Таким образом, взаимосвязь удовлетворенности образом собственного тела и здоровье являются одной из узких, но актуальных проблем для исследования в современной психологии женщин.

Цель исследования состояла в исследовании связи удовлетворенности собственным телом и отношением к здоровью у молодых девушек.

Для ее достижения необходимо было выявить, как «видят» себя девушки с помощью опросника образа собственного тела О.А. Скугаревского, С.В. Сивухи [12], измерить по шкале удовлетворенность внешностью по методике «ШУСТ» О.А. Скугаревского, измерить уровень отношения к своему здоровью с помощью теста-опросника Р.А. Березовской, интерпретировать и сравнить полученные результаты, выявить связь с помощью корреляционного анализа Ч. Спирмена.

В исследовании приняли участие 20 девушек в возрасте от 18 до 25 лет, являющихся студентками, обучающимися в Кубанском государственном университете.

При обработке сырых данных по методикам: «Опросник образа собственного тела» (О.А.Скугаревский, С.В.Сивуха); «Шкала удовлетворенности 
внешностью» (О.А. Скугаревский); «Опросник отношения к здоровью» (Р.А. Березовская), были вычислены средние значения по шкалам, а также проведен корреляционный анализ.

Согласно результатам исследования по методике О.А. Скугаревского, С.В. Сивухи выявлено, что 50\% молодых девушек удовлетворены состоянием своего тела. Что касается остальных, то другие 50\% молодых девушек показали своими результатами, что их не удовлетворяет состояние собственного тела.

Итак, для молодых девушек удовлетворенность образа собственного тела является существенным свойством личности.

Согласно результатам исследования следующей методики - О.А. Скугаревского «Шкала удовлетворенности внешностью» мы получили следующие результаты. Для более цельной картины мы объединили 5 шкал (очень низкий уровень, низкий уровень, средний уровень, высокий уровень и очень высокий уровень) в 3 - высокий, средний и низкий уровни удовлетворенности внешностью.

Было выявлено, что 50\% имеют высокий уровень удовлетворенности собственной внешностью, другие $25 \%$ средне удовлетворены своей внешностью и последние, 25\% имеют низкий уровень удовлетворенности собственной внешностью.

Итак, для молодых девушек удовлетворенность собственной внешностью является существенным свойством личности.

Согласно результатам исследования по методике Р.А. Березовской выявлено, что у 50\% опрошенных молодых девушек адекватное отношение к своему здоровью. Что касается остальных 50\% девушек, то уровень отношения к своему здоровью ниже адекватного. Таким девушкам не свойственно уделять должное внимание состоянию своего здоровья, что не скажешь про тех, у кого выявлено адекватное отношение к своему здоровью.

Итак, для молодых девушек удовлетворенность отношением к здоровью является существенным свойством личности.

В результате корреляционного анализа были прокоррелированы все три методики (5 шкал). Оказалось, что прослеживается прямая взаимосвязь только 
между ценностно-мотивационной шкалой опросника отношения к здоровью Р.А. Березовской и образом собственного тела по шкале О.А. Скугаревского, С.В. Сивухи (r= 0,27), остальных корреляций не было выявлено. Итак, мы видим, что связаны только 2 методики, причем по 1 шкале.

То есть, мы можем сделать вывод, что у молодых девушек удовлетворенность собственным телом и отношением к здоровью - не связаны.

Таким образом, в современных исследованиях уделяется большое внимание изучению удовлетворенности девушек образом собственного тела и предпринимаются попытки изучения компонентов, влияющих на них, в частности - здоровья, как одного из компонентов удовлетворенности.

Выявленные эмпирические факты позволяют сделать вывод, что молодые девушки больше озадачены образом собственного тела, своим внешним видом, такими отдельными критериями внешности, как: рост тела, его размер, вес, пропорции, лицо, прическа и многими другими - все это как одно отдельное переживание в образе собственного Я. Что касается отношения к своему здоровью, то в ходе анализа эмпирических результатов выявлено, что половина девушек имеет положительное отношение к здоровью, а половина не удовлетворены отношением к своему здоровью. В дальнейшем следует перспектива исследования особенностей взаимосвязи компонентов на более большей выборке, т.к. наша выборка недостаточна для глубокого рассмотрения и изучения этих двух выделенных компонентов.

Полученные результаты можно использовать в психологическом консультировании с девушками, имеющими: 1) неадекватноевосприятие своего здоровья; 2) нарушения ввосприятии образа собственного тела; 3) нарушения пищевого поведения.

Результаты исследования могут быть полезны как с практической, так и теоретической стороны, для всех участников образовательной сферы и не только.

\section{Список литературы}

1. Ананьев В.А. Введение в психологию здоровья / В.А. Ананьев. - СПб.: БПА, 1998. 
2. Белогай К.Н. Образ тела: структурные компоненты и динамическая характеристика / К.Н. Белогай, Т.Е. Варакина, И.С. Морозова; под ред. И.С. Морозовой // Психология телесности: от субъективизации образа к трансформации динамических параметров: сборник статей. - Кемерово: КемГУ, 2017. - C. 6-17.

3. Васильева О.С. Психология здоровья человека: эталоны, представления, установки: учеб. пособие для студ. высш. учеб. Заведений / О.С. Васильева, Ф.Р. Филатов. - М.: Издательский центр «Академия», 2001. - 352 с.

4. Дурнева М.Ю. Формирование отношения к телу и пищевого поведения у девушек подросткового и юношеского возраста: дисс ... канд. психол. наук: 19.00.13 / М.Ю. Дурнева; Моск. гор. психол.-пед. ун-т. - Москва, 2014. - С. 2028.

5. Козьмина Л.Б. Самоотношение и самооценка как предикторы психологического благополучия личности студентов психологов / Л.Б. Козьмина // Историческая и социально-образовательная мысль. - 2013. - №1 . - С. 193-197.

6. Налчаджян А.А. Психологическая адаптация: механизмы и стратегии. М. :Эксмо, 2010. - 368 с.

7. Непп М. Невербальное общение / М. Непп, Дж. Холл. - СПб.: ПраймЕврознак, 2004. - 254c.

8. Пилишвили Т.С. Особенности удовлетворенности своим телом у молодых женщин / Т.С. Пилишвили, В.С. Едименченко // Мир науки, культуры, образования. - 2018. - №6 (73). - С. 396-397.

9. Подорога В.А.Феноменология тела. Введение в философскую антропологию / В.А. Подорога. - М., 1995. - 341 с.

10. Рамси Н. Психология внешности / Н. Рамси, Д. Харкорт. - Спб: Питер, 2009. -256 c.

11. Сиерес Д. О различных подходах к понятию «здоровье» / Д. Сиерес, В. Гавидия // Школа здоровья. - 1998. - Т.5. - №1. - С.7-16. 
12. Скугаревский О.А. Образ собственного тела: разработка инструмента для оценки / О.А. Скугаревский, С.В. Сивуха // Психологический журнал 2006. - №4. - C. 40-48.

13. Соколова Е.Т. Самосознание и самооценка при аномалиях личности / Е.Т. Соколова. - М.: Издво МГУ, 1990. - 215 с.

14. Шевеленкова Т.Д. Психологическое благополучие личности. Обзор основных концепций и методик исследования / Т.Д. Шевеленкова // Психологическая диагностика. - 2005. - №3. - С. 95- 129.

15. Cash T.F. \& Henry P.E. Women's body images: The results ofanational survey in the U.S.A. Sex Roles. - 1995. - Vol. 33 (1-2). - Pp. 19-28.

16. Chang F.M., Jarry J.L., Kong M.A. Appearance investment mediates the association between fear of negative evaluation and dietary restraint // Body Image. 2014 - Vol. 11. - P. 72-76.

17. Stiman M., Leavy P., and Garland A. Heterosexual Female and Male Body Image and Body Concept in the Context of Attraction Ideals // Electronic Journal of Human Sexuality. - 2009. - Vol. 12. - Oct. 21. 